Jarosław Kita

Uniwersytet Łódzki

(iD)

ORCID ID: 0000-0002-8374-2848
OBLICZA WOJNY

TOM $2 \cdot$ ARMIA KONTRA NATURA

ŁÓDŹ 2020 • ISBN 978-83-8220-057-7 • s. 175-196

http://dx.doi.org/10.18778/8220-057-7.09

\title{
NATURA KONTRA ARMIA IWANA PASKIEWICZA PODCZAS WYPRAWY NA WĘGRY W 1849 ROKU
}

\begin{abstract}
Streszczenie. W czerwcu 1849 r. rosyjska armia interwencyjna pod dowództwem feldmarszałka Iwana Paskiewicza wkroczyła na Węgry celem udzielenia wsparcia wojskom austriackim. Po stronie Węgrów walczyło kilka tysięcy Polaków i część z nich pozostawiła pamiętniki dotyczące wydarzeń węgierskiej Wiosny Ludów. Z kolei w armii rosyjskiej służyli także Polacy, ale egodokumentów wytworzonych przez nich znamy bardzo mało. Dlatego też jest to interesujące i mało wykorzystywane źródło. W niniejszym tekście, na podstawie przede wszystkim wspomnień uczestników walk na Węgrzech w 1849 r., podjęto refleksję historyczną nad problemem, w jakim stopniu natura wpływała na działania prowadzone przez wojska carskie. Autorzy pamiętników pisali o tym niewiele, a jeżeli już podejmowali ten problem, to wskazywali na dwie zasadnicze kwestie, a mianowicie panujące upały i szerzącą się epidemię cholery. Ponadto pewnymi problemami, chociaż najpewniej nie najważniejszymi dla pamiętnikarzy, były przeprawy przez wielkie rzeki, np. Cisę, oraz długotrwałe marsze nieraz bez jedzenia i wody.
\end{abstract}

Słowa kluczowe: natura, armia rosyjska, Iwan Paskiewicz, Węgry, Wiosna Ludów

Wiosna Ludów na Węgrzech ma już swoją obszerną literaturę przedmiotu. Pomimo to można jeszcze znaleźć pewne aspekty badawcze, które pozwalają na podjęcie interesujących, chociaż niebyt szeroko zakreślonych zagadnień. Właśnie jeden $\mathrm{z}$ takich tematów stał się przedmiotem moich rozważań w tym tekście. Zainteresowała mnie kwestia, czy natura była czynnikiem sprzyjającym czy też utrudniającym wyprawę armii rosyjskiej pod dowództwem feldmarszałka Iwana Paskiewicza na Węgry celem wsparcia wojsk austriackich w tłumieniu węgierskiej Wiosny Ludów. Na początek kilka uwag wprowadzających. Kiedy wiosną 1849 r. udało się Węgrom przejąć inicjatywę w starciu z wojskami 
austriackimi car Rosji Mikołaj I zdecydował się na udzielenie zbrojnego wsparcia młodemu cesarzowi Franciszkowi Józefowi I w ramach zobowiązań Świętego Przymierza ${ }^{1}$. W odezwie wydanej 8 maja 1849 r. cesarz rosyjski tak m.in. uzasadniał swoją decyzję o wsparciu Austrii: „Manifestem naszym z d. 26 marca 1848 r. zawiadomiliśmy naszych wiernych poddanych o nieszczęściu jakie zachodnią część Europy dotknęło, a zarazem oświadczyliśmy, że jesteśmy gotowi stanąć naprzeciw nieprzyjaciół naszych [...]. Rozruchy i bunty na zachodzie nie wzięły dotąd końca [...] przeciwnie wzmocnił się bunt tamtejszy bandami naszych polskich zdrajców z roku 1831 i innych zbiegów², wygnańców, włóczęgów i awanturników rozmaitych narodów i groźne przybrał proporcje [...], a Rosja wypełni święte swoje powołanie"3.

Stąd też to „powołanie” wojska rosyjskie zaczęły wypełniać już na początku maja 1849 r., kiedy to przekroczyły granice monarchii habsburskiej, wkraczając do Galicji i po krótkich przygotowaniach ruszając na Węgry na pomoc armii austriackiej. Na czele wojsk interwencyjnych stanął uznany wódz, jakim był feldmarszałek Iwan Fiodorowicz Paskiewicz, mający za sobą kilka zwycięskich kampanii, w tym stłumienie powstania listopadowego ${ }^{4}$. Na początku czerwca rosyjska dywizja dowodzona przez gen. Fiodora (Teodora) Siergiejewicza Paniutina ${ }^{5}$ przekroczyła granicę węgierską w Pozsony i wzmocniła siły austriackie

1 Wojska węgierskie odnosząc szereg zwycięstw w kampanii wiosennej 1849 r. przyczyniły się do ogłoszenia przez rewolucyjny parlament węgierski obradujący w Debreczynie niepodległości kraju (19 IV) i zrzucenia zależności od dynastii habsburskiej. Prezydentem-gubernatorem został Lajos Kossuth, a na czele niezależnego od Wiednia rządu narodowego stanął Bertalan Szemere. Zastąpił on na tym stanowisku obejmującego nowy urząd L. Kossutha. Vide: W. Felczak, Historia Wegier, Wrocław 1983; I. W. RoberTs, Nicholas I and the Russian Intervention in Hungary, London 1991.

2 Jedną z ważnych przyczyn rosyjskiej interwencji był właśnie masowy udział Polaków w walkach na Węgrzech. Car Mikołaj I miał obawiać się, aby ich udział w tych wydarzeniach nie doprowadził do wzniecenia kolejnego polskiego powstania, które objęłoby tereny wszystkich zaborów. Vide: S. PomaRAŃSKI, Wojskowa stużba Traugutta, Warszawa 1929, s. 7.

3 „Czas” 1849, nr 76, s. 4.

${ }^{4}$ Iwan Fiodorowicz Paskiewicz (1782-1856) - generał feldmarszałek, książę warszawski, namiestnik Królestwa Polskiego w latach 1832-1856. Uczestnik walk z Napoleonem I, dowodził wojskami rosyjskimi na Kaukazie i w wojnie przeciw Turcji, stłumił powstanie listopadowe. Prowadził politykę rusyfikacyjną w Królestwie Polskim - tzw. noc paskiewiczowska. W 1849 r. stał na czele interwencyjnego korpusu rosyjskiego wspierającego siły habsburskie na Węgrzech. Jako dowódca Armii Naddunajskiej brał udział w wojnie krymskiej, vide: A.P. Ks. Szczerbatow, Rzady księcia Paskiewicza w Królestwie Polskim (1832-1847), Warszawa 1900.

${ }^{5}$ Fiodor (Teodor) Siergiejewicz Paniutin (1790-1865) - ukończył Korpus Paziów. W 1812 r. walczył przeciw Napoleonowi I m.in. pod Borodino i Małojarosławcem. Uczestniczył również w kam- 


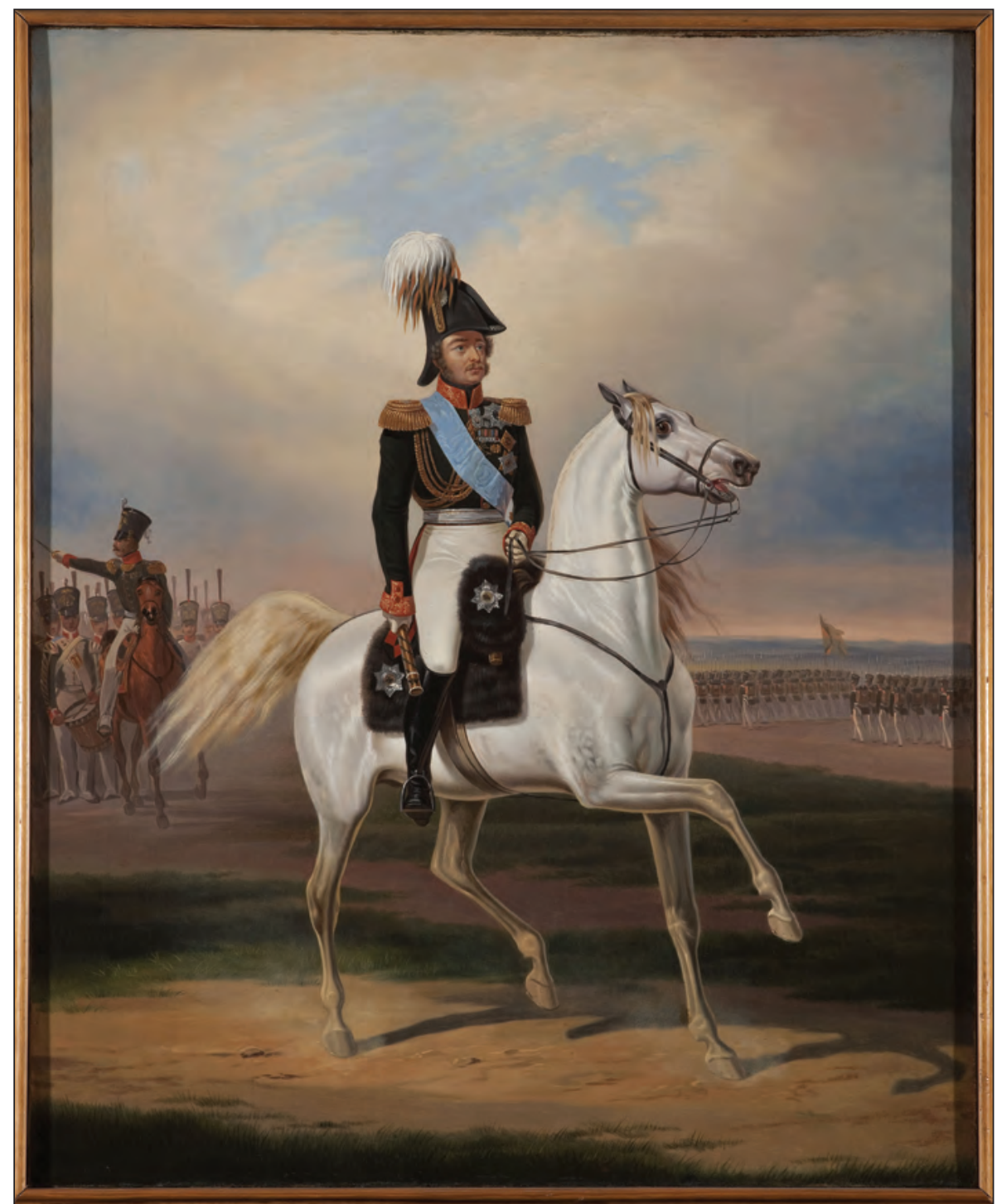

Ryc. 1. Feldmarszałek Iwan Paskiewicz (J. SuchOdOLSKI, 1841)

paniach antynapoleońskich w latach 1813-1814. W 1826 r. został dowódcą Rylskiego Pułku Piechoty, a w 1828 r. mianowany był na stopień generał-majora. Uczestniczył w wojnie z Turcją (1828-1829) i został ranny w bitwie pod Bajazetem. Po Iwanie Paskiewiczu został głównodowodzącym armii rosyjskiej na linii kaukaskiej. Uczestniczył w tłumieniu powstania listopadowego w 1831 r., podczas którego dostał się do polskiej niewoli. Po stłumieniu powstania został mianowany na stopień generał-lejtnanta. W czasie interwencji na Węgrzech w 1849 r. był jednym z aktywniejszych rosyjskich dowódców 
dowodzone przez gen. Juliusa Jacoba von Haynau ${ }^{6}$, atakujące od zachodu z kierunku Wiednia. Natomiast w połowie tego miesiąca główne siły armii I. Paskiewicza (około 70 000) poprzez Przełęcz Dukielską uderzyły z północy na wojska węgierskie od strony Preszowa, Koszyc i Bańskiej Bystrzycy. Ponadto liczący około 30000 korpus gen. Aleksandra Nikołajewicza von Lüdersa ${ }^{7}$ wkroczył do Siedmiogrodu. Było to ogromne wsparcie dla cesarza Franciszka Józefa I, gdyż interwencyjne siły rosyjskie składające się z trzech głównych korpusów liczyły łącznie około 114000 piechoty, około 15000 jazdy i 462 działa $^{8}$.

W odezwie cara Mikołaja I pojawiło się odniesienie do polskich emigrantów, nazwanych „bandami polskich zdrajców”, którzy uczestniczyli w wydarzeniach Wiosny Ludów. Udział Polaków po stronie Węgrów został szczegółowo opisany zarówno przez historyków polskich, jak i węgierskich? . Według ustaleń

i dowodził 9 dywizją piechoty. W 1851 r. uzyskał awans na generała piechoty, uczestniczył także w przegranej przez Rosję wojnie krymskiej. W przededniu wybuchu powstania styczniowego pełnił w Królestwie Polskim funkcję wojennego generał-gubernatora warszawskiego i przewodniczącego Komisji Sądu Wojennego w Cytadeli Warszawskiej. W 1861 r. został powołany na członka Rady Państwa, vide: W. Ramming, Der Feldzug in Ungarn und Siebenbürgen im Sommer des Jahres 1849, Pesth 1850, s. 16; N. Kicka, Pamiętniki, oprac. J. Dutkiewicz i T. Szafrański, Warszawa 1972, s. 547.

${ }^{6}$ Julius Jacob von Haynau (1786-1853) - austriacki generał znany ze swego bezwzględnego postępowania wobec ludności cywilnej i powstańców podczas tłumienia Wiosny Ludów we Włoszech i na Węgrzech. Przeciwnicy nazywali go „Hieną z Brescii” i „Wisielcem Arada”. Vide: R. von SchöNHALs, Biographie des k.k. Feldzeugmeisters Julius Freiherrn von Haynau, Wien 1875.

7 Aleksandr Nikołajewicz von Lüders (1790-1874) - generał rosyjski, uczestnik wojny fińskiej 1808 r., brał udział w tłumieniu powstania listopadowego, w 1843 r. dowodził korpusem, który thumił powstanie Czeczenów. W 1849 r., jako dowódca V korpusu uczestniczył w interwencji przeciw powstaniu węgierskiemu, na terenie Siedmiogrodu (Transylwanii) toczył walki przeciw wojskom węgierskim dowodzonym przez gen. Józefa Bema. Od XI 1861 r. do VI 1862 r. był namiestnikiem Królestwa Polskiego. Po powrocie do Sankt Petersburga otrzymał tytuł hrabiowski i wszedł do Rady Stanu. Vide: Lidiers, Aleksandr Nikotajewicz, graf (АиАЕРС, Александр Николаевич, граф), https://slovari.yandex. $\mathrm{ru} /$ книги/Военная энцикмопедия/Аидерс, Александр Николаевич, граф/ [dostęp: 23 I 2020].

${ }^{8}$ [J. BuŁHARYN], Rys wojny wegierskiej w latach 1848-1849 przez jenerata Jerzego Butharyna, krzyżów wojskowych kawalera, Paryż 1852, s. 282.

9 Tytułem przykładu vide: I. Kovács, Polacy w wegierskiej Wiośnie Ludów 1848-1849. „Byliśmy z Wami do końca”, Warszawa 1999; IDEm, Polacy w wegierskiej Wiośnie Ludów, „Prace Komisji Środkowoeuropejskiej” 2001, t. 9, s. 29-41; IDEM, Nieznani polscy bohaterowie powstania wegierskiego 1848-1849, Warszawa 2010; IDEM, Honwedzi, emisariusze, legioniści. Stownik biograficzny polskich uczestników Wiosny Ludów na Wegrzech 1848-1849, Kraków 2016; S. Schnür-Pepeowski, Polacy i Wegrzy. Opowieść dziejowa, Lwów 1898; D.B. KaCnelson, Polscy spiskowcy a rewolucja wegierska 1848-1849 (w świetle archiwów lwowskich), „Biuletyn Ukrainoznawczy” 2001, nr 7, s. 18-31; J. MIDzıo, W takt marszu Rakoczego. Udziat Polaków w wegierskiej Wiośnie Ludów 1848-1849, Warszawa 
najlepszego badacza tego problemu, Istvana Kovácsa, Polaków walczących u boku Węgrów było ponad 5000, w tym około 3000 skupionych w Legionie Polskim dowodzonym przez gen. Józefa Wysockiego ${ }^{10}$. Wydarzenia te znalazły również odzwierciedlenie we wspomnieniach polskich uczestników powstania węgierskiego z lat 1848-1849 ${ }^{11}$. Natomiast zdecydowanie mniej uwagi poświęcono naszym rodakom, którzy z różnych przyczyn walczyli po stronie przeciwnej, czyli w szeregach armii austriackiej czy rosyjskiej ${ }^{12}$, gdyż niezbyt to pasuje do wizji Polaka - bojownika o „wolność naszą i waszą”. Z różnych przekazów można dowiedzieć się, iż w korpusie rosyjskim skierowanym do interwencji na Węgrzech znalazła się grupa oficerów i żołnierzy pochodzenia polskiego służących w armii carskiej (nawet tak znanych jak chociażby przyszły dyktator powstania styczniowego, Romuald Traugutt, w 1849 r. oficer (chorąży) w batalionie saperów w interwencyjnej armii I. Paskiewicza) ${ }^{13}$. Ich bezpośrednich

1966; Pod wspólnym sztandarem. Polacy w wegierskiej Wiośnie Ludów. Közös lobogó alatt. Lengyelek a magyar Szabadságharcban, red. A. NAGY, L. ÁBRÁN, Budapest 1999; E. KozŁowski, Legion Polski na Wegrzech 1848-1849, Warszawa 1983.

${ }^{10}$ I. KovÁcs, Honwedzi, emisariusze, legioniści..., passim. Cf. [J. Wysocki], Pamiętnik Generata Wysockiego z czasów kampanii węgierskiej w roku 1848 i 1849 (Z ilustracjami), Warszawa 1899, passim; E. KozŁowski, op. cit., passim.

11 Vide: m.in.: [J. Szyc], Legiony polskie na Wegrzech. Wspomnienia oficera tychże legionów, Poznań 1850; [J. FALKOwSKI], Wspomnienia z roku 1848-1849 przez autora "Obrazów z życia kilku ostatnich pokoleń w Polsce", Poznań 1879; Bem w Siedmiogrodzie i w Banacie. Z pamiętników Józefa Wtadystawa Ruckiego, bytego oficera legionu polskiego, Lwów 1866; [W. PONIŃski], Wspomnienia z lat ubiegtych. Listy do moich synów, skreślit jenerat Wtadystaw hr. Poniński, Kraków 1902; J. FALKowSKI, Wspomnienia z roku 1848 i 1849, cz. 1-3, przedmowa T. GRUŻEwsKI, Warszawa 1908; F. BAGIEŃsKi, Wspomnienia starego Wotyniaka, oprac. Z. Sudolski, Warszawa 1987; [J. BuŁHARYN], Rys wojny wegierskiej...; [J. Wysocki], Pamiętnik Generata Wysockiego...; P. WodzIński, Wspomnienia żotnierza-tutacza (1848-1863), oprac. S. KRYNICKI, Lwów 1912; W. ZAMOYSKI, Jenerat Zamoyski 1803-1868, t. 5, 1847-1852, Poznań 1922.

${ }^{12} \mathrm{O}$ udziale Polaków w armii habsburskiej i bratobójczych walkach prowadzonych z polskimi ochotnikami z powstańczej armii węgierskiej vide: m.in.: M. BACZKowski, Galicjanie w armii austriackiej wobec wydarzeń lat 1848-1849, [w:] Galicja i jej dziedzictwo, t. 12, Galicja w 1848 roku, red. W. Bonusiak, J. Buszko, Rzeszów 1999, s. 94-95; E. KozŁowski, op. cit., s. 166-167, 284-285.

${ }^{13}$ Romuald Traugutt zanim został ostatnim dyktatorem powstania styczniowego odbył służbę w armii carskiej. Po ukończeniu gimnazjum w Świsłoczy, jako junkier wstąpił do 3 Batalionu Saperów i rozpoczął wojskowy staż w Żelechowie. W II 1848 r. po zdaniu egzaminów w Petersburgu został mianowany chorążym. W następnym roku jego jednostka weszła w skład armii feldmarszałka Iwana Paskiewicza. Pomiędzy 12 a 29 V 1849 r. stacjonował w Krakowie, będąc w składzie formacji dowodzonej przez generała-lejtnanta Grigorija Ch. Zassa (Sassa). W dniach 4-8 VI forsowano Karpaty, 


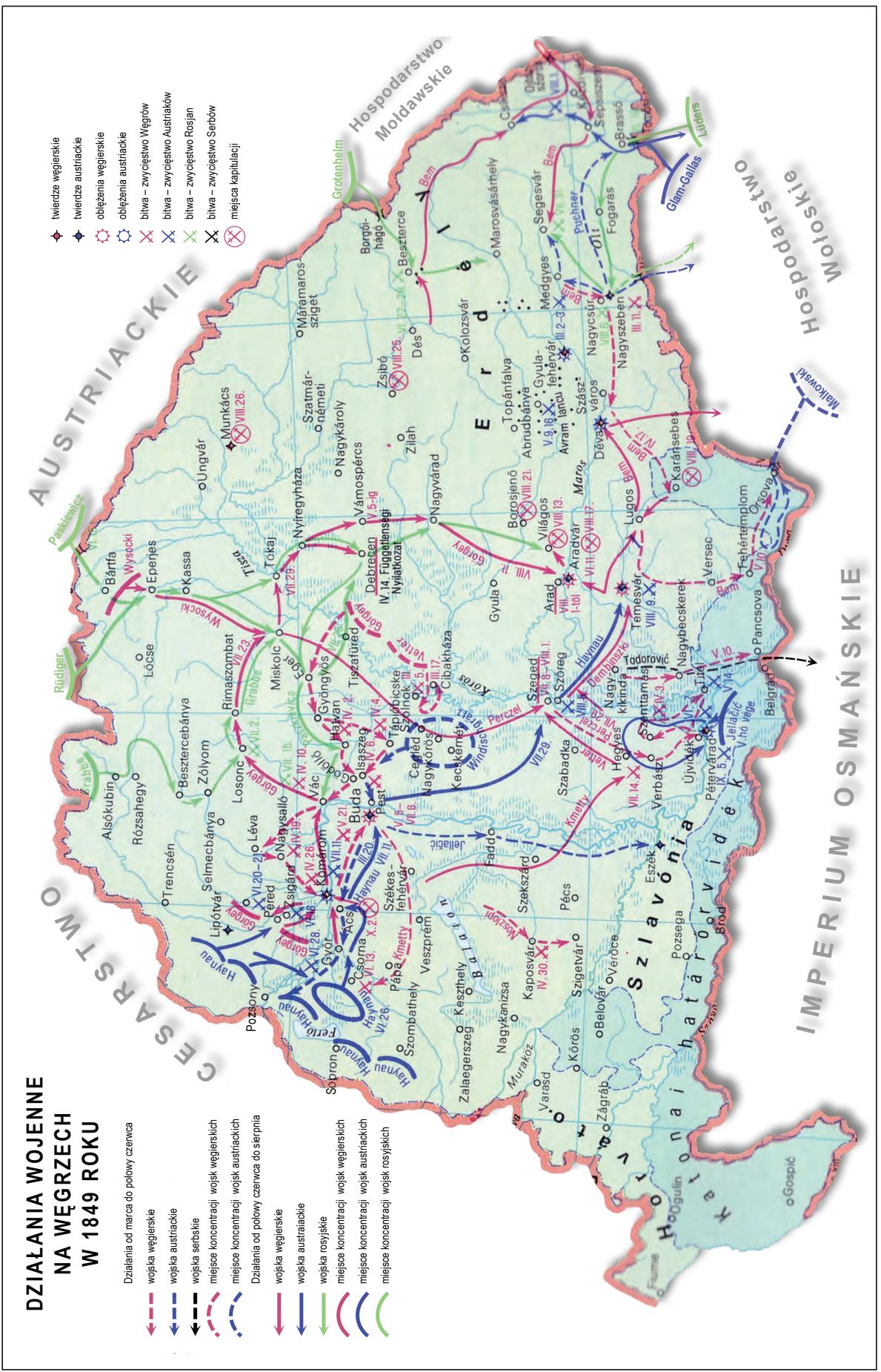


relacji z udziału w tej kampanii zachowało się niewiele, stąd też warto wykorzystać te, które udało się dotychczas odnaleźć. Należałoby poszukać w tych materiałach źródłowych odpowiedzi na zasadnicze pytania: jaki był ich stosunek do powstania węgierskiego, do tłumienia którego zostali wysłani, a także jakie były ich uczucia wobec swoich rodaków walczących w armii narodowej (honwedów)? Ja jednak zdecydowałem się w tych relacjach szukać odpowiedzi na inne jeszcze pytanie, a mianowicie, czy pozostawili oni jakieś informacje dotyczące wpływu szeroko zakreślonego pojęcia „natura” ${ }^{\prime 4}$ na przebieg rosyjskiej kampanii na Węgrzech w 1849 r. Podczas realizacji podjętego tematu refleksji poddam jedynie kilka aspektów, a mianowicie warunki naturalne, które mogły mieć wpływ na przemieszczanie się i działania jednostek rosyjskich, czyli ukształtowanie terenu i rodzaj podłoża, sieć wodna, szata roślinna, czynniki klimatyczne, a ponadto czynniki chorobotwórcze.

Relacji polskich oficerów służących w armii rosyjskiej interweniującej na Węgrzech w 1849 r. zachowało się najpewniej niewiele. W niniejszym tekście zostały wykorzystane - diariusz z lat 1848-1849 autorstwa Józefa Zabokrzyckiego, zachowany w rękopisie oraz dziennik z kampanii węgierskiej regularnie spisywany przez Władysława Tomaszewicza w okresie od 4 maja do 29 września 1849 r. wydany drukiem przez Tadeusza Epszteina ${ }^{15}$. Autor pierwszego z egodokumentów, Józef Zabokrzycki, był pułkownikiem wojsk rosyjskich, w latach

a od 15 VI R. Traugutt pracował przy fortyfikowaniu Koszyc. Podczas walk na Węgrzech przyszło mu stawać w walce przeciwko swoim rodakom wspierającym Madziarów. Uczestniczył w bitwach pod Preszowem (8-12 VI), Koszycami (15 VI), Gyöngyös (29 VI), Vac (3-5 VII), Temeszwarem (9 VIII) i Világos (13 VIII). R. Traugutt jako saper prowadził głównie roboty inżynieryjne, takie jak budowa mostów (m.in. na Dunaju i Cisie), forsowanie wąwozów, budowa fortyfikacji i umocnień (m.in. Koszyce, Debreczyn). Po zakończeniu walk 6 X 1849 r. powrócił do Królestwa Polskiego. Za udział w tłumieniu powstania węgierskiego został mianowany do stopnia podporucznika i otrzymał gratyfikację pieniężną. Vide: A. Janowski, Wykaz stużby wojskowej Romualda Traugutta, „Ziemia” 1933, R. 23, nr 1, s. 2; S. PoMARAŃsKi, op. cit., s. 1-14.

14 Według Stownika jezzka polskiego, red. W. Doroszewski, https://sjp.pwn.pl/doroszewski/ natura;5456548.html [dostęp: 12 VI 2019], pojęcie „natura” definiowane jest jako: „całokształt rzeczy i zjawisk tworzących wszechświat, świat (bez wytworów pracy ludzkiej); ziemia i woda, wraz z żyjącymi na nich i w nich roślinami i zwierzętami; przyroda”; „przyroda jako siła kształtująca organizmy żywe, zwłaszcza ludzi”. Niemal identyczne elementy definiujące pojęcie "natura” znajdziemy w Stowniku jezzyka polskiego PWN, https://sjp.pwn.pl/szukaj/natura [dostęp: 12 VI 2019]: „przyroda, zachodzące w niej zjawiska i procesy”, „przyroda jako siła kształtująca organizmy żywe, zwłaszcza ludzi”.

15 Archiwum Główne Akt Dawnych, Zbiór Anny z Potockich Ksawerowej Branickiej, Archiwalia różnej proweniencji, Pamiętnik putkownika wojsk rosyjskich, rkps, sygn. 1/338/0/2/628 [dalej: 
1837-1848 dowodził pułkiem strzelców ukraińskich, 6 grudnia 1847 r. mianowany na generał-majora. Od 20 lipca 1848 r. był dowódcą 1 brygady 14 dywizji piechoty w korpusie feldmarszałka I. Paskiewicza. Pochodził z ziemiańskiej rodziny mającej majątek na Ukrainie ${ }^{16}$. W kampanii na Węgrzech brał udział również jego jedyny syn, 23-letni porucznik Bolesław Zabokrzycki, od wiosny 1848 r. adiutant naczelnika sztabu IV korpusu wojsk rosyjskich. Zmarł młodo na tyfus w Odessie, zaraz po zakończeniu wojny krymskiej ${ }^{17}$.

J. Zabokrzycki, Dziennik]; W. Tomaszewicz, Dziennik oficera rosyjskiego z kampanii wegierskiej 1849 roku, oprac., wstępem i przypisami opatrzył T. Epsztein, Warszawa 2010.

${ }^{16}$ Józef Kalasanty Zabokrzycki (Żabokrzycki) (ur. 1800?-1871?) - oficerem zostal już $11 \mathrm{~V}$ 1813 r. stąd też podawana data jego urodzenia może być nieprawdziwa. Po zakończeniu kampanii na Węgrzech nadal pozostawał w czynnej służbie osiągając kolejne zaszczyty. W dniu 6 XII 1854 r. uzyskał awans na generał-lejtnanta. W spisie generałów za 1859 r. figuruje jako dowódca 6 dywizji piechoty, od IV 1860 r. został urlopowany, a następnie przeniesiony do rezerwy. Za wszelkie zasługi wojenne był wielokrotnie odznaczany, m.in. ordery: Św. Anny czwartej klasy - 1813, Św. Anny drugiej klasy - 1845, Św. Włodzimierza trzeciej klasy - 1850, Św. Stanisława pierwszej klasy - 1852, Św. Anny pierwszej klasy - 1860. Był dwukrotnie (?) żonaty. Drugą (?) żoną była Inessa (Filipina) z Woydów, córka prezydenta Warszawy (1816-1830) Karola Fryderyka Woydy (1771-1846) i Teresy z Kuźniczów. Zmarła 22 VIII 1853 r. po „długiej a b. dotkliwej chorobie” w Odessie, pozostawiając matkę, męża i córkę. Generał J. Zabokrzycki zmarł najpewniej w drugiej połowie 1871 r., gdyż w spisie generałów na 1872 r. już nie znajdujemy jego nazwiska. Vide: Spisok gienieratam po starszynstwu, isprawlen po 21 diekabria 1852, Sanktpietierburg 1852 (Список генералам по стариинству, исправлен по 21 декабря 1852, Санктпетербург 1852), s. 363; Spisok gienieratam po starszynstwu, isprawlen po 7 jaanwaria 1856, Sanktpietierburg 1856 (Список генералам по стариинству, исправлен по 7 яанваря 1856, Санктпетербург 1856), s. 272; Spisok gienieratam po starszynstwu, isprawlen po 1 jaanwaria 1859, Sanktpietierburg 1859 (Список генералам по стариинству, исправлен по 1 яанваря 1859, Санктпетербург 1859), s. 179; Spisok gienieratam po starszynstwu, isprawlen po 1 marta 1861, Sanktpietierburg 1861 (Список генералам по стариинству, исправлен по 1 марта 1861, Санктпетербург 1861), s. 243; Spisok gienieratam po starszynstwu, isprawlen po 1 jaanwaria 1863, Sanktpietierburg 1863 (Список генералам по стариинству, исправлен по 1 яанваря 1863, Санктпетербург 1863), s. 211; Spisok gienieratam po starszynstwu, isprawlen po 1 maja 1871, Sanktpietierburg 1871 (Список генералам по стариинству, исправлен по 1 мал 1871, Санктпетербург 1871), s. 172; J. і E. Szulcowie, Cmentarz ewangelicko-reformowany w Warszawie. Zmarli i ich rodziny, Warszawa 1989, s. 281; Nekrologi „Kuriera Warszawskiego” 1821-1939, t. 3, 1853-1858, oprac. A.T. TyszKa, Warszawa 2007, s. 72, 337; H. z DziaŁYŃSkich B£ęDowska, Pamiątka przesztości. Wspomnienia z lat 1794-1832, oprac. i wstęp K. Kostenicz i Z. MaKowieckA, Warszawa 1960, s. 252 (występuje jako mjr Żabokrzycki, sąsiad Zygmunta Działyńskiego z Trojanowa).

17 Bolesław Zabokrzycki (1826 - 5 II 1856 Odessa) - syn Józefa Kalasantego Zabokrzyckiego z pierwszego małżeństwa. Jego nekrolog został zamieszczony w „Kurierze Warszawskim” - „Bolesław Zabokrzycki, rotmistrz, kawaler kilku orderów, jedyny syn generał-lejtnanta Józefa Zabokrzyckiego, 
Z kolei autor dziennika, Władysław Tomaszewicz (1820-1895), wywodzący się również z ziemiańskiego środowiska z terenów Ukrainy, po ukończeniu szkoły junkrów otrzymał przydział do 36 orłowskiego pułku piechoty (strzelców) księcia Iwana Paskiewicza. W grudniu 1848 r. wraz z pułkiem został skierowany do Częstochowy. Na początku maja 1849 r. jego jednostka, która weszła w skład korpusu interwencyjnego, została skierowana do Galicji, poprzez Skałę i Miechów dotarła do Krakowa, a stąd wyruszyła na Węgry. W chwili rozpoczęcia interwencji w monarchii habsburskiej W. Tomaszewicz w randze porucznika był kwatermistrzem swojego pułku, będącego częścią 9 dywizji piechoty dowodzonej przez generała F. Paniutina ${ }^{18}$. Jego dziennik jest sumiennie prowadzonym zapisem wydarzeń, niemal każdy dzień doczekał się przynajmniej krótkiej charakterystyki. Autor był naocznym świadkiem i uczestnikiem opisywanych, czasem dramatycznych zdarzeń.

Analizie poddałem również materiały wspomnieniowe, w tym wytworzone przez rosyjskich oficerów i innych uczestników wyprawy I. Paskiewicza w 1849 r., oraz memuary Polaków służących w szeregach armii honwedów ${ }^{19}$.

naczelnika korpusu pilnującego pobrzeża Morza Azowskiego, młodzieniec najpiękniejszych nadziei dla kraju; zm. 5 II 1856 w Odessie na tyfus nie dożywszy lat 30”. Vide: Nekrologi „Kuriera Warszawskiego"..., s. 337.

18 Władysław Tomaszewicz (27 VI 1820 Dubno - 28 II 1895 Kielce) - pochodził z Wołynia, gdzie jego ojciec - Wincenty - był najpewniej współwłaścicielem lub dzierżawcą majątku Hruszwica należącego w pierwszej połowie XIX w. do rodziny Jełowickich. Jego matką była Józefa z Lipińskich. Miał siostrę oraz brata Andrzeja (Jędrzeja), który również uczestniczył w kampanii węgierskiej. Obaj bracia zdecydowali się na karierę w wojsku carskim. Prawdopodobnie za udział w kampanii węgierskiej otrzymał austriacki Order Żelaznej Korony, był także kawalerem Orderu Św. Anny, czwartej klasy. Od 1853 r. wszedł w służbę w żandarmerii (komendant w Mławie, Warszawie, Łomży). Skończył karierę w randze pułkownika i po przejściu na emeryturę zamieszkał w Kielcach. Jego żoną była Jadwiga z Kołaczkowskich (6 VI 1832 - 26 II 1902), córka Aleksandra Mikołaja Kołaczkowskiego h. Habdank, właściciela majątku Kamyk z przyległościami (pow. częstochowski) i Anny Karoliny z Królikiewiczów. Córką Władysława i Jadwigi z Kołaczkowskich Tomaszewiczów była znana lekarka Anna z Tomaszewiczów Dobrska. Ponadto inne dzieci: Paulina, Wincenty, Zofia, Aleksander, Michał. Vide: „Kurier Warszawski” 1895, nr 61, s. 7; Z. FILAR, Anna Tomaszewicz-Dobrska. Karta z dziejów polskich lekarek, Warszawa 1959; W. TomaszeWicz, op. cit., s. 12-20.

19 Vide: przyp. 11. Ponadto: I. Rosonczy, Postawa korpusu oficerskiego armii carskiej na Wegrzech w 1849 r., [w:] Pod wspólnym sztandarem (1848-1849). Polacy w wegierskiej Wiośnie Ludów, Közös lobogó alatt..., s. 133-139; A.S. BudiŁowicz, O znaczenii russkogo pochoda $1849 \mathrm{~g}$. dla awstro-ugorskich narodow, „Bibliotieka żurnala” (А.С. Будицович, О значении русского похода 1849 г. для австро-угорских народов, „Библиотека журнала «Русин»”) 2018, t. 8, сz. 1, s. 6-26; I. Roszoncy, 
Ze względu na ograniczoną objętość artykułu zarysuję kilka najistotniejszych refleksji będących efektem przeprowadzonych analiz materiału źródłowego.

Pierwszym problemem, który natura stawiała przed korpusem rosyjskim, był łańcuch Karpat leżący wówczas na granicy Królestwa Galicji i Lodomerii oraz Węgier. Marsz przez tereny podgórskie i przełęcze z pewnością nie należałby do łatwych dla masy wojska i taborów ze sprzętem i żywnością. W tym wypadku niesprzyjające uwarunkowania terenowe, przynajmniej dla części sił interwencyjnych, zostały pokonane dzięki osiągnięciom cywilizacyjnym. Od świtu 10 maja 1849 r. na krakowskim dworcu kolejne jednostki wchodzące w skład 9 dywizji piechoty gen. F. Paniutina zostały załadowane do wagonów kolejowych i „drogą żelazną” wyruszyły w kierunku Wiednia. Była to dywizja piechoty składająca się z czterech pułków piechoty (29 - czernichowski, 34 - siewski, 35 - briański, 36 - orłowski), czyli 16 batalionów (około 14000 żołnierzy) i miała na wyposażeniu $48 \mathrm{dział}(4 \text { baterie })^{20}$. Żołnierze jechali w odkrytych wagonach, siedząc naprzeciwko siebie. Ze wspomnień rosyjskich oficerów wynika, iż taka podróż miała też swoje negatywne strony, jak chociażby to siedzenie bez ruchu naprzeciw siebie. Jednocześnie w swoich memuarach podkreślali oni, że po przekroczeniu granicy, podczas podróży przez tereny pruskie i na Morawach, witani byli radośnie przez tamtejszych mieszkańców, licznie zgromadzonych wzdłuż linii kolejowej²1. W podróż koleją nie zabrano formacji kawalerii, co spowodowało niezadowolenie samego cesarza Mikołaja I i zmusiło I. Paskiewicza do tłumaczenia się przed władcą z tego kroku. Wieczorem żołnierze rosyjskiego korpusu interwencyjnego mieli kilkugodzinny odpoczynek w Oderbergu (Bohumin) na Morawach, dokąd dotarli w wagonach pruskich i rosyjskich. Następnego dnia rano, po przesiadce w wagony austriackie, dotarli do miasta Hradisch (Uherske Hradiste - Czechy), około $150 \mathrm{~km}$ od stolicy Austrii, skąd po blisko

\footnotetext{
Rolżeleznodorożnogo soobszczenija w okazanii Rossijej wojennoj pomoszczi Awstrii w maje 1849 g., „Sławianskij mir w trietjem tysiaczeletii” (И. РОшонци, Роль железнодорожного сообщения в оказании Россией военной помощи Австрии в мае 1849 г., „САавянский мир в третьем тысячеметии”) 2018, $\mathrm{N}^{\circ} 3-4$, s. 32-49.

${ }^{20}$ Pomiędzy 10 a 15 V 1849 r. przetransportowano 189 oficerów, 13749 żołnierzy niższych stopni, 977 koni artyleryjskich i oficerskich, 48 dział, 88 sztuk bydła, 167 skrzyń i ładunków. Więcej szczegółów dotyczących części jednostek podaje Józef ZABOKrZYCKI w Dzienniku, s. 19-26.

${ }^{21}$ Wspominali o podróży m.in. rosyjscy oficerowie: Lignicki, A. Aleksiejenko - dowódca 6 kompanii 18 pułku piechoty, Siemiakin. Podaję za: I. Roszoncy, Rol..., s. 46.
} 
dwóch tygodniach przygotowań podjęli marsz na przeciwnika, czyli armię honwedów. Dzięki wykorzystaniu kolei wojska gen. F. Paniutina przejechały około $350 \mathrm{~km}$, a tym samym uniknęły długotrwałego marszu. Transport całej dywizji wraz ze sprzętem trwał od 10 do 15 maja. Według ówczesnych obliczeń transport kolejowy był trzykrotnie szybszy niż zwykły marsz. Ale oprócz pozyskiwania cennego czasu zaletą tego przemieszczania się wojska było zmniejszenie niemal do zera strat wśród żołnierzy. Natomiast podczas zwykłego marszu, w zależności od warunków pogodowych, jakości dróg i przepraw, chorób i warunków kwaterunkowych, straty takie wynosiły 3-6\% stanu osobowego ${ }^{22}$. Korpus ten został wysłany wcześniej, przed głównymi siłami I. Paskiewicza, celem zabezpieczenia Wiednia przed odnoszącymi sukcesy oddziałami węgierskimi, operującymi nad Dunajem w okolicach Preszburga, nie tak daleko od stolicy Habsburgów ${ }^{23}$. Był to pierwszy na taką skalę transport jednostek wojskowych realizowany w ramach współpracy międzynarodowej. W realizację tego przedsięwzięcia zaangażowane zostały władze wojskowe, cywilne i kompanie kolejowe trzech państw - Rosji, Austrii i Prus. Należy podkreślić, iż w historii wojskowej imperium Romanowów transport ten był pierwszym doświadczeniem w przewozie wojsk rosyjskich koleją do teatru operacji wojskowych ${ }^{24}$. Rosyjskie wojska gen. F. Paniutina miały to szczęście, że pod koniec 1847 r. uruchomiona została linia Kolei Krakowsko-Górnośląskiej, która łączyła się z Koleją Górnośląską - była gotowa w 1846 r. - i dzięki temu uzyskano połączenie z Wiedniem²5. Bezpośrednia podróż z Krakowa do Wiednia trwała wówczas 13 godzin. Dowództwo rosyjskie

22 M. Annienkow, Wojennaja stużba żeleznych dorog, „Wojennyj sbornik” (М. Анненков, Boеннал служба железныхх дорог, „Военный сборник”) 1876, º 3, s. 116.

${ }^{23} \mathrm{Na}$ ile celowe było to działanie i dlaczego korpus gen. Paniutina nie dotarł do samego Wiednia, vide: I. Roszoncy, op. cit., s. 32-49.

${ }^{24}$ Ibidem, s. 33.

25 Budowę linii Kolei Krakowsko-Górnośląskiej rozpoczęto wiosną 1847 r., a już 13 X tego roku trasę łączącą Kraków z Mysłowicami przejechała pierwsza lokomotywa o nazwie „Kraków”. Była to pierwsza linia kolejowa, jaką wybudowano w Galicji. W Mysłowicach linia łączyła się z pruską Koleją Górnośląską (z Wrocławia, ukończoną w 1846 r.), a w Maczkach z budowaną wówczas Koleją Warszawsko-Wiedeńską w Królestwie Polskim, ukończoną w 1848 r., vide: J. SKWARCZYŃsKI, Rozwój sieci kolejowejpod zaborem austriackim, „Inżynier Kolejowy” 1926, nr 8-9, s. 215-219; S.M. KozIARSKI, Sieć kolejowa Polski w latach 1842-1918, Opole 1993, s. 11-15, 95-100; A. i L. Czarnotowie, Kolej Krakowsko-Górnoślaska, „Gazeta Mysłowicka”, 7 XI 2014, https://gazetamyslowicka.com/historia/2014/11/kolej-krakowsko-gornoslaska [dostęp: 21 I 2020]. 
wykorzystywało później kolej do zaopatrywania swoich oddziałów w żywność, amunicję, przesyłano tą drogą korespondencję, przewożono rannych i chorych, podróżowali kurierzy i dowódcy ${ }^{26}$.

Konstatacje powyższe dotyczą jednak tylko części sił rosyjskich, gdyż główny trzon armii feldmarszałka I. Paskiewicza w początkach czerwca 1849 r. musiał przejść przez przełęcze górskie kierując się do węgierskiej wówczas Słowacji ${ }^{27}$. Jakie utrudnienia ze strony górskich warunków terenowych mógł napotykać na swej drodze może świadczyć pozostawiony w dzienniku W. Tomaszewicza opis jego przeprawy przez Przełęcz Dukielską już podczas powrotu do Królestwa Polskiego po klęsce Węgrów: „Droga, jaką miałem od Orlika do Rymanowa, zostanie na długo w pamięci, jadąc między górami, musiałem wciąż przebywać potoki przepełnione deszczową wodą z gór. Potoki te tu były szybkie i głębokie, że kilka razy miałem pełną bryczkę wody, a pęd onej dwa razy tylko co mnie z bryczką i z końmi w dół potoku nie uniósł" 28 .

Warto wyjaśnić, iż obecnie odległość drogowa z Orlika na Słowacji do Rymanowa w Galicji to tylko niespełna $50 \mathrm{~km}$. W 1849 r. droga ta była krótsza, ale prowadziła jeszcze bardziej poprzez tereny górskie. Dlatego też zanim ruszyły główne siły księcia warszawskiego, jak tytułowano I. Paskiewicza, straż przednia pod dowództwem gen. Grigorija Christoforovicza von Zassa $\left(\right.$ Sassa ${ }^{29}$, w składzie której był m.in. batalion saperów, w którym służył chorąży Romuald Traugutt, miała za zadanie budować i reperować górskie drogi i przeprawy ${ }^{30}$.

26 I. Roszoncy, Rol..., s. 45.

27 Vide: J.ZавокRZycki, Dziennik, s. 19-26.

28 W. Tomaszewicz, op. cit., s. 103 (5/17 IX 1849).

${ }^{29}$ Grigorij Christoforovicz von Zass (1797-1883) - gen. rosyjskiej kawalerii (od 1877). Już jako młody człowiek walczył w ostatnich kampaniach przeciw Napoleonowi I. W latach dwudziestych i trzydziestych XIX w. służył na Kaukazie, m.in. uczestniczył w wojnie rosyjsko-tureckiej (1828-1829). Podczas interwencji na Węgrzech w 1849 r. uczestniczył w bitwach pod Vac i Debreczynem. Odznaczony orderami: Św. Jerzego czwartej klasy i Św. Włodzimierza czwartej klasy, Św. Anny pierwszej i drugiej klasy, Św. Stanisława pierwszej klasy. Vide: G.C. Atarszczıкow, Zamietki starogo kawkazca o wojennoj i administratiwnoj diejatielnosti na Kawkazie gienierat-lejtienanta barona Grigorija Christoforowicza Zassa: (Syroj matieriat dla istorii pokorienija Kawkaza), „Wojennyj sbornik” (Г.С. АТАрщиков, Заметки старого кавказица о военной и административной деятельности на Кавказе генерал-лейтенанта барона Григория Христофоровича Засса: (Сьрой материал для истории покорения Кавказа), „Военный сборник”) 1870, t. 74, Nº 8, s. 309-333.

30 S. Pomarański, op.cit., s. 8. 
Przeprawa przez tereny górskie była z pewnością znacznym wyzwaniem dla wojsk feldmarszałka I. Paskiewicza, ale z drugiej strony pewną rekompensatą mógł być stosunek miejscowej ludności - Słowaków i Rusinów, zamieszkujących tereny ówczesnych północnych Węgier - do wkraczających korpusów Mikołaja I. Przemieszczając się z Dukli w stronę Miszkolca wojska I. Paskiewicza mogły liczyć na dostawy żywności i niezbędnych wyrobów, a miejscowa ludność witała żołnierzy carskich z entuzjazmem. Na taką pomoc i postawę mogli też liczyć żołnierze A. Lüdersa wkraczając do Siedmiogrodu zamieszkanego przez Rumunów. Było to sporym zaskoczeniem dla żołnierzy rosyjskich i dopytywali swoich oficerów, gdzie w końcu są ci wrogowie - Węgrzy ${ }^{31}$.

Wspomniany autor dziennika, W. Tomaszewicz, miał poważne problemy z pokonywaniem bryczką najczęściej niewielkich, chociaż bystro płynących, górskich potoków. Należało więc sprawdzić w źródłach, czy sieć rzeczna na terenie operacyjnym rosyjskiej armii interwencyjnej stwarzała jakieś poważne problemy? Przecież na obszarze wchodzącym w skład ówczesnych Węgier było kilka dużych rzek z Dunajem, Cisą, Wagiem, Rabą, Morawą i Popradem na czele. Przeprawa przez nie mogła stanowić poważne wyzwanie. Analiza wykorzystywanych źródeł pozwala sformułować tezę, iż cieki wodne raczej bardzo nie przeszkadzały w przemieszczaniu się armii rosyjskiej. Na największych rzekach znajdowały się porządne, najczęściej kamienne mosty, których obie walczące strony nie niszczyły bądź nie były w stanie zniszczyć. Most łańcuchowy na Dunaju w stolicy Węgier budowany w latach 1839-184932, W. Tomaszewicz nazwał wręcz arcydziełem, chociaż jeszcze nie był dokończony ${ }^{33}$. Wszystko to sprawiało, że większość przepraw nie stanowiła poważniejszego problemu. Pojawiał się on raczej podczas pokonywania rzek, na których znajdowały się niewielkie, drewniane mosty. Żołnierze z armii honwedów, aby utrudnić przeprawę

31 Notatka hrabiego Ridigiera. Podaję za: A.S. BudiŁowicz, op. cit., s. 23.

32 Most wybudowany został według projektu angielskiego inżyniera Williama Tierney’a Clarka. Prace przy budowie rozpoczęto w 1839 r., a oddano go ostatecznie do użytku 20 XI 1849 r. Już rok wcześniej można było z niego korzystać. Most stanowił pierwsze stałe połączenie pomiędzy leżącymi po obu stronach Dunaju - Budą i Pesztem. Był wówczas pierwszym kamiennym mostem na odcinku rzeki, leżącym w granicach ówczesnych Węgier. W trakcie węgierskiego powstania w 1848 r. gen. austriacki Heinrich von Hentzi podjął próbę wysadzenia mostu, jednak wybuch ustawionych na moście beczek z prochem nie spowodował większych zniszczeń. M. BANACH, Most tańcuchowy w Budapeszcie, https://www.smartage.pl/most-lancuchowy-w-budapeszcie/ [dostęp: 12 I 2020].

33 W. TomaszewiCz, op. cit., s. 79-80 (9/21 VII 1849). 
wrogowi, palili takie mosty i wykorzystując ciek wodny jako naturalną przeszkodę, ostrzeliwali wojska rosyjskie i austriackie, gdy te podejmowały próbę przedostania się na drugi brzeg ${ }^{34}$. Tak było chociażby 3 sierpnia 1849 r. podczas walk w Szegedzie (Segedynie). Węgrzy wycofali się paląc drewniany most na Cisie: „[...] jednakże kiedy Austriacy zaczęli nawodzić [ściągać na wodę - J.K.] pontony, nieprzyjaciel ukryty na drugim brzegu rzeki odkrył [otworzył - J.K.] ogień z domów, zza parkanów, spoza drzew, słowem, zewsząd zaczęły się strzały armatnie i ręcznej broni. W odwet temu wprowadzono osiem dział naszej artylerii [...] zapalono rakietami domy przeciwnego brzegu rzeki, skąd ukryci Węgrzy nie dozwalali przeprawić nasze wojska, lecz pożar i strzały zmusiły ich ustąpić tej pozycji. Po czym natychmiast przeprawili się strzelcy austriaccy"35.

Z kolei to samo wydarzenie gen. J. Wysocki w swych wspomnieniach opisał w sposób następujący: „Austryacy zaczęli budować most, z zamiarem zdobycia sobie przemocą przeprawy. Kapitan Jordan (Zygmunt) bronił jej mężnie z małym oddziałem, i chociaż ranny w nogę, pozostał do końca na placu boju. Jednakże nie pomogły te usiłowania. Nieprzyjaciel pod opieką silnej artylerii dokończył mostu nad wieczorem, a część jego wojska, przeszedłszy na lewy brzeg Cissy, zajęła usypane tam szańce"36.

Szybko i sprawnie budowane prowizoryczne mosty pontonowe pozwalały więc na przeprawę w miejscach, gdzie zniszczone zostały stałe przeprawy mostowe. Opisów takich w wykorzystywanych przeze mnie egodokumentach jest jednak niewiele. Można te informacje uzupełnić śledząc chociażby służbę wojskową R. Traugutta jako sapera i jego działania na Węgrzech w 1849 r. Brał on udział chociażby w naprawie kilku mostów na Cisie zniszczonych przez wojska honwedów będące w odwrocie ${ }^{37}$. Właśnie rzeka Cisa stanowiła relatywnie największą przeszkodę na drodze armii rosyjskiej. Należy jednocześnie pamiętać, że zanim przybyły na Węgry wojska rosyjskie, podczas ofensywy prowadzonej przez wojska honwedów, mosty te palili żołnierze armii habsburskiej, aby bezpiecznie się wycofać. Działo się tak chociażby pomiędzy 5 a 21 czerwca 1849 r., kiedy walki nad rzeką Wag „pokazały cesarskim niemożebność przeparcia

${ }^{34}$ [J. Wysocki], Pamiętnik Generata Wysockiego..., s. 118-119; [J. Szyc], Legiony polskie na Wegrzech..., s. 52.

35 W. Tomaszewicz, op. cit., s. 86 (22 VII/3 VIII 1849).

36 [J. Wysocki], Pamiętnik Generata Wysockiego..., s. 119.

37 S. Pomarański, op. cit., s. 8-9. 
Węgrów w tych pozycjach, zatem popaliwszy mosty ustąpili Madziarom"38. Ze względu na fakt, iż Węgrzy mieli mało „pontonierów” odbudowywanie przez nich mostów nawet na niewielkich rzekach, jak np. Gran, zajmowało im dużo czasu, co utrudniało prowadzenie działań ofensywnych ${ }^{39}$.

Wojska rosyjskie wraz z armią austriacką, którą wspierały, w zasadzie codziennie były $\mathrm{w}$ drodze pokonując różne odległości pomiędzy kolejnymi miejscami wyznaczonymi na spoczynek. Podczas swojego pobytu na terenie ówczesnych Węgier pokonały setki kilometrów. Trudno jednak znaleźć w pamiętnikach i dziennikach narzekania ich autorów na te długie przemarsze po drogach węgierskich. Jeśli już pojawiają się, to przede wszystkim w kontekście toczonych bitew i potyczek wymagających przemieszczania się (najczęściej marszów pościgowych) bez spożywania posiłków. Po bitwie odbytej pod Temesvar (Timisoara) 9 sierpnia 1849 r. jeden z pamiętnikarzy zanotował: „Tak wyruszywszy z ostatniego noclegu o 3 z rana żołnierz nasz 20 godzin był na nogach i prócz chleba nic nie jadł”40. Należy jednak podkreślić, że autorzy tych egodokumentów byli oficerami i to często $\mathrm{z}$ wyższą rangą, albo pełnili funkcje w kwatermistrzostwie. Przemieszczali się więc konno, bryczkami i wozami, a tym samym nie odczuwali tak mocno przebytych odległości jak szeregowcy, pokonujący poszczególne etapy na własnych nogach, niosąc przy tym żołnierski ekwipunek. Niestety nie udało się odnaleźć jakiegokolwiek dokumentu, którego autorem byłby prosty żołnierz. Warto jeszcze podkreślić, że teren Węgier, w znacznym stopniu równinny, względnie pagórkowaty, charakteryzował się przy tym dobrymi, przepuszczalnymi i suchymi glebami, dzięki czemu rosyjskie wojska interwencyjne nie miały problemów z przemieszczaniem się chociażby po mokradłach i błotach wyschniętych w wyniku panujących wysokich temperatur. Ponadto były to tereny o małej lesistości, poza terenami podgórskimi, dzięki czemu armia honwedów nie miała wielu szans na prowadzenie działań o charakterze partyzanckim.

Czy w takim wypadku natura tak bardzo sprzyjała, albo inaczej zbytnio nie przeszkadzała w działaniach armii I. Paskiewicza podczas interwencji na Węgrzech? Największym problemem, na który niejednokrotnie wskazywano,

\footnotetext{
${ }^{38}$ Z pamiętników żotnierza, „Dziennik Literacki” 1862, nr 66, s. 530.

39 J. FALKowski, Wspomnienia z roku 1848 i 1849..., cz. 3, s. 103.

40 W. Tomaszewicz, op. cit., s. 89 (28 VII/9 VIII 1849).
} 
były panujące wówczas na Węgrzech nieznośne upały. Począwszy od pierwszych dni po wkroczeniu w czerwcu do końca sierpnia palące słońce i wysoka temperatura niezmiernie utrudniały życie, a szczególnie długie marsze. Tytułem przykładu, w swoim dzienniku W. Tomaszewicz co najmniej kilkunastokrotnie zanotował informacje w stylu: „Upał nie do ścierpienia. Jednak żołnierze nasi nie ulegali znużeniu od gorąca, stali wszyscy w najlepszym porządku”¹, albo „Tydzień minął, jak tu ciągle trwają upały i dlatego z północy wychodzimy z kwater, by uniknąć skwaru słońca w południe”ł2, a jeszcze inny zapis: „Upał więcej jak kiedykolwiek dziś nam dokuczał, bo stanąwszy pod gołym niebem, zostawieni byliśmy skwarowi słonecznemu, który nielitościwie nas palił i po-

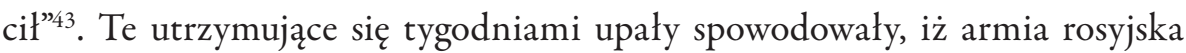
została zmuszona do nocnych przemarszów. W ciągu dnia żołnierze starali się skryć przed palącym słońcem w wystawianych rankiem po całonocnym marszu szałasach lub chałupach wiejskich. Upały panowały niemal przez cały okres pobytu wojsk rosyjskich na Węgrzech, a sytuacje kiedy „deszcz do rąbka nas zmoczył i tak jeszcze po przybyciu na biwuaki [sic!] częstował. Według mnie, wolę deszcz jak upał, chociaż wprawdzie jedno i drugie nie jest przyjemne" ${ }^{\text {"4 }}$ czy „czas pogodny zmienił się, deszcz rzęsisty i zimny padać począ?”5 bywały opisywane tylko sporadycznie.

Panujące upały powodowały, iż na niektórych terenach brakowało wystarczających zasobów wody pitnej, tym bardziej że miejscowa ludność w obawie przed przemarszami wojsk opuszczała swoje siedziby i nie gromadziła wody na zapas, a studnie wysychały z powodu panujących wysokich temperatur. Z niewielkich zasobów wody korzystała jeszcze armia powstańcza, a maszerujące za nią wojska rosyjskie tym bardziej narażone były na „puste” studnie. Jeden z pamiętnikarzy pisał: „Kraj zaś między Cisą a Dunajem którędy Percel ${ }^{46}$ wojsko

${ }^{41}$ Ibidem, s. 52 (14/26 V 1849).

42 Ibidem, s. 57 (21 V/2 VI 1849).

43 Ibidem, s. 58 (23 V/4 VI 1849).

${ }^{44}$ Ibidem, s. 72 (14/26 VI 1849).

45 [J. BuŁHARYN], Rys wojny wegierskiej..., s. 342.

${ }^{46}$ Mór Perczel (1811-1899) - generał armii honwedów. Szczególnie wyróżnił się w walce z wojskami serbskimi. Przeciwnik polityczny L. Kossutha. Po klęsce powstańców uciekł przez Turcję do Londynu. Pozwolono mu powrócić na Węgry w 1867 r., został wpływowym politykiem w ramach powstałych wówczas Austro-Węgier. Podaję za: Perczel von Bonyhád Mór, [w:] Österreichisches Biographisches Lexikon, 1815-1950, Bd. 7, Lfg. 35, 1978, s. 413. 
poprowadził, był od Keczkemet aż do Szegedyna zupełnie ogołocony ze wsiów i mieszkańców, a co większa z wody, bo na tej płaszczyźnie ledwie gdzieniegdzie znajdują się pusty, czyli folwarki. Studnie są bardzo rzadkie i te kiedy posuchy panują najczęściej niektóre są bez wody. [...] stąd też wojsko trudów wielkich, z przyczyny gorąca, piaszczystej okolicy i braku wody doznało"’37.

Należy przecież pamiętać, że do przygotowania potraw i ugaszenia pragnienia, a także zaspokojenia najprostszych czynności higienicznych tysięcy zgromadzonych w jednym miejscu żołnierzy, potrzebne były znaczne zasoby wody. Ponadto niezbędna była do napojenia setek koni kawalerzystów i taborowych.

Wysokie temperatury i panująca susza utrudniały zarazem armii honwedów obronę, a tym samym pomagały rosyjskim wojskom interwencyjnym prowadzić działania zaczepne. Pisząc o ostatniej fazie wojny, gen. Jerzy Bułharyn wskazywał właśnie także na te elementy natury, które utrudniały działania Węgrom i ich polskim sojusznikom. W swoim Rysie wojny wegierskiej... zanotowat: „szańce zostały założone na tak wielką skalę, że pięćdziesiąt tysięcy wojska na obsadzenie ich nie wystarczało; nadto założenie tych szańców było zrobione wtedy, kiedy wylew Cisy znaczne tworzył do przystępu do Szegedyna przeszkody, a teraz przy nader niskim stanie rzeki, i przy upałach, nie tylko woda, ale nawet i błota kompletnie osuszone, przystęp do miasta i mostu łatwym czyniły”48.

Drugim poważnym problemem, który nękał żołnierzy feldmarszałka I. Paskiewicza była rozprzestrzeniająca się coraz bardziej cholera. Na szczęście były to dopiero początki kolejnej wielkiej epidemii tej ostrej i zaraźliwej choroby zakaźnej przewodu pokarmowego, jaka cyklicznie nawiedzała Europę ${ }^{49}$. Jak można wyczytać w źródłach, w niektórych regionach natura zbierała żniwo wśród żołnierzy, którzy zarazili się szczepami przecinkowca cholery. „Od wczoraj w obozie naszym zjawiła się cholera. Jest ona w mieście [Pressburg - Bratysława] od 1 czerwca i dlatego uważam za omyłkę naszego naczelnego wodza jenerała Paniutina, iż nas tu tak bardzo przybliżył. [...] Wczoraj zachorowało

47 [J. BuŁHARYN], Rys wojny wegierskiej..., s. 308-309.

48 Ibidem, s. 315.

49 W latach 1848-1852 wybuchła w tej części Europy druga pandemia cholery zbierająca okrutne żniwo. Największe nasilenie przypadło na początek lat pięćdziesiątych XIX w. stąd podczas pacyfikowania rewolucji węgierskiej nie doszło jeszcze do masowych zachorowań wśród żołnierzy. Cholera, jej dawniejsze epidemie u nas, przyczyny, objawy, zapobieganie i leczenie, oprac. B. DzIERżawski, O. Hewelke, W. Janowski i J. Zawadzki, Warszawa 1892, s. 4-8. 
na tę słabość 4 żołnierzy, dziś już 20 do szpitala odesłano" ${ }^{50}$. Cieszyli się więc niezmiernie, kiedy mogli jak najszybciej opuścić te węgierskie rejony, w których zapadalność na cholerę była zdecydowanie podwyższona. „Z powodu, że cholera nie na żarty szerzyć się poczęła w obozie naszym, przeniesiono nas dziś o $4 \mathrm{z}$ rana do pobliskich wiosek" ${ }^{51}$.

Cholera szerzyła się również w szeregach armii węgierskiej i wśród Polaków walczących w Legionie Wysockiego. Jadący z misją na Węgry Władysław Zamoyski najbardziej właśnie obawiał się panującej epidemii, pisał o tym do wuja, księcia Adama Jerzego Czartoryskiego: „Z Paryża wiadomość o «stanie oblężenia» mniej mnie zajmuje jak brzydka cholera" ${ }^{\text {2 }}$.

Reasumując, chciałbym sformułować spostrzeżenia o charakterze uogólniającym. Analiza dzienników i pamiętników pozwala wysnuć wniosek, iż piszący, niezależnie czy służyli w korpusie I. Paskiewicza czy też w Legionie Polskim lub narodowej armii węgierskiej, nie rozpisywali się zbytnio o problemach związanych z wpływem czynników i sił natury na przebieg wyprawy rosyjskiej i prowadzonych walk. Pomimo to można odnaleźć szereg informacji na ten temat, chociaż najczęściej dosyć lakonicznych. Co ciekawe, pisali o tym przede wszystkim Polacy będący w służbie rosyjskiej. W memuarach stworzonych w kręgu polskich oficerów, najczęściej mających wysoką szarżę, tylko sporadycznie można odnaleźć przekazy dotyczące wpływu czynników natury na przebieg działań. Najwięcej uwagi poświęcono niezmiernie wysokiej temperaturze utrzymującej się przez kilka tygodni oraz zaczynającej szerzyć się epidemii cholery. Dominowały elementy czysto militarne i polityczne, najczęściej o silnym zabarwieniu osobistym i emocjonalnym.

\section{BIBLIOGRAFIA}

\section{Źródła archiwalne}

Archiwum Główne Akt Dawnych

Zbiór Anny z Potockich Ksawerowej Branickiej, Archiwalia różnej proweniencji, Pamiętnik putkownika wojsk rosyjskich, rkps, sygn. 1/338/0/2/628.

\footnotetext{
50 W. Tomaszewicz, op.cit., s. 59 (25 V/6 VI 1849).

51 Ibidem, s. 61 (28 V/9 VI 1849).

52 W. Zamoyski, op.cit., t. 5, 1847-1852, Poznań 1922, s. 228.
} 


\section{Źródła drukowane}

Atarszczikow G.S., Zamietki starogo kawkazca o wojennoj i administratiwnoj diejatielnosti na Kawkazie gienierat-lejtienanta barona Grigorija Christoforowicza Zassa: (Syroj matieriat dla istorii pokorienija Kawkaza), „Wojennyj sbornik” (Атарщиков Г.С., Заметки старого кавказиа о военной и административной деятельности на Кавказе генерал-лейтенанта барона Григория Христофоровича Засса: (Сьцой материал дяя истории покорения Кавказа), „Военный сборник”) 1870, t. 74, No 8, s. 309-333.

Bagieński F., Wspomnienia starego Wotyniaka, oprac. Z. Sudolski, Warszawa 1987.

Błędowska z Działyńskich H., Pamiątka przesztości. Wspomnienia z lat 1794-1832, oprac. i wstęp K. Kostenicz i Z. Makowiecka, Warszawa 1960.

[Bułharyn J.], Rys wojny wegierskiej w latach 1848-1849 przez jenerata Jerzego Butharyna, krzyżów wojskowych kawalera, Paryż 1852.

"Czas" 1849.

[Falkowski J.], Wspomnienia z roku 1848 i 1849, cz. 1-3, przedmowa T. Grużewski, Warszawa 1908.

[Falkowski J.], Wspomnienia z roku 1848-1849 przez autora „Obrazów z życia kilku ostatnich pokoleń w Polsce", Poznań 1879.

Kicka N., Pamiętniki, oprac. J. Dutkiewicz i T. Szafrański, Warszawa 1972.

„Kurier Warszawski” 1895.

[Poniński W.], Wspomnienia z lat ubiegtych. Listy do moich synów, skreślit jenerat Wtadystaw hr. Poniński, Kraków 1902.

Ramming W., Der Feldzug in Ungarn und Siebenbürgen im Sommer des Jahres 1849, Pesth 1850.

[Rucki J.W.], Bem w Siedmiogrodzie i w Banacie. Z pamiętników Józefa Wtadystawa Ruckiego, bytego oficera legionu polskiego, Lwów 1866.

Spisok gienieratam po starszynstwu, isprawlen po 1 jaanwaria 1859, Sanktpietierburg 1859 (Список генералам по стариинству, исправлен по 1 яанваря 1859, Санктпетербург 1859).

Spisok gienieratam po starszynstwu, isprawlen po 1 jaanwaria 1863, Sanktpietierburg 1863 (Список генералам по старшинству, исправлен по 1 яанваря 1863, Санктпетербург 1863).

Spisok gienieratam po starszynstwu, isprawlen po 1 maja 1871, Sanktpietierburg 1871 (Список генералам по старшинству, исправлен по 1 мая 1871, Санктпетербург 1871).

Spisok gienieratam po starszynstwu, isprawlen po 1 marta 1861, Sanktpietierburg 1861 (Список генералам по старшинству, исправлен по 1 марта 1861, Санктпетербург 1861). 
Spisok gienieratam po starszynstwu, isprawlen po 21 diekabria 1852, Sanktpietierburg 852 (Список генералам по старшинству, исправлен по 21 декабря 1852, Санктпетербург 1852).

Spisok gienieratam po starszynstwu, isprawlen po 7 jaanwaria 1856, Sanktpietierburg 1856 (Список генералам по старшинству, исправлен по 7 яанваря 1856, Санктпетербург 1856).

[Szyc J.], Legiony polskie na Wegrzech. Wspomnienia oficera tychże legionów, Poznań 1850.

Tomaszewicz W., Dziennik oficera rosyjskiego z kampanii wegierskiej 1849 roku, oprac., wstępem i przypisami opatrzył T. Epsztein, Warszawa 2010.

Wodziński P., Wspomnienia żotnierza-tutacza 1848-1863, oprac. S. Krynicki, Lwów 1912.

[Wysocki J.], Pamiętnik Generata Wysockiego z czasów kampanii węgierskiej w roku 1848 i 1849 (Z ilustracjami), Warszawa 1899.

Zamoyski W., Jenerat Zamoyski 1803-1868, t. 5, 1847-1852, Poznań 1922.

Z pamiętników żotnierza, „Dziennik Literacki” 1862, nr 66.

\section{Opracowania}

Annienkow M., Wojennaja stużba żeleznych dorog, „Wojennyj sbornik” (Анненков M., Военная служба железньх дорог, „Военный сборник”) 1876, º 3 .

Baczkowski M., Galicjanie w armii austriackiej wobec wydarzeń lat 1848-1849, [w:] Galicja i jej dziedzictwo, t. 12, Galicja w 1848 roku, red. W. Bonusiak, J. Buszko, Rzeszów 1999.

Budiłowicz A.C., O znaczenii russkogo pochoda 1849 g. dla awstro-ugorskich narodow, „Bibliotieka żurnala (Будимович A.С., О значении русского похода 1849 г. для австро-угорских народов, „Библиотека журнама «Русин»”) 2018, t. 8, сz. 1, s. 6-26.

Cholera, jej dawniejsze epidemie u nas, przyczyny, objawy, zapobieganie i leczenie, oprac. B. Dzierżawski, O. Hewelke, W. Janowski i J. Zawadzki, Warszawa 1892.

Felczak W., Historia Wegier, Wrocław 1983.

Filar Z., Anna Tomaszewicz-Dobrska. Karta z dziejów polskich lekarek, Warszawa 1959.

Janowski Al., Wykaz stużby wojskowej Romualda Traugutta, „Ziemia” 1933, R. XXIII, nr 1.

Kacnelson D.B., Polscy spiskowcy a rewolucja wegierska 1848-1849 (w świetle archiwów lwowskich), „Biuletyn Ukrainoznawczy” 2001, nr 7, s. 18-31.

Kovács I., Honwedzi, emisariusze, legioniści. Stownik biograficzny polskich uczestników Wiosny Ludów na Wegrzech 1848-1849, Kraków 2016.

Kovács I., Nieznani polscy bohaterowie powstania wegierskiego 1848-1849, Warszawa 2010.

Kovács I., Polacy w węgierskiej Wiośnie Ludów, „Prace Komisji Środkowoeuropejskiej” 2001, t. 9, s. 29-41. 
Kovács I., Polacy w węgierskiej Wiośnie Ludów 1848-1849. „Byliśmy z Wami do końca”, Warszawa 1999.

Koziarski S.M., Sieć kolejowa Polski w latach 1842-1918, Opole 1993.

Kozłowski E., Legion Polski na Wegrzech 1848-1849, Warszawa 1983.

Midzio J., W takt marszu Rakoczego. Udziat Polaków w wegierskiej Wiośnie Ludów 1848-1849, Warszawa 1966.

Nekrologi „Kuriera Warszawskiego” 1821-1939, t. 3: 1853-1858, oprac. A.T. Tyszka, Warszawa 2007.

Perczel von Bonyhád Mór, [w:] Österreichisches Biographisches Lexikon, 1815-1950, Bd. 7, Lfg. 35, 1978, s. 413.

Pod wspólnym sztandarem (1848-1849). Polacy w wegierskiej Wiośnie Ludów. Közös lobogó alatt. Lengyelek a magyar Szabadságharcban, red. A. Nagy, L. Ábrán, Budapest 1999.

Pomarański S., Wojskowa stużba Traugutta, Warszawa 1929.

Roberts I.W., Nicholas I and the Russian Intervention in Hungary, London 1991.

Rosonczy I., Postawa korpusu oficerskiego armii carskiej na Wegrzech w 1849 r., [w:] Pod wspólnym sztandarem (1848-1849). Polacy w wegierskiej Wiośnie Ludów. Közös lobogó alatt. Lengyelek a magyar Szabadságharcban, red. A. Nagy, L. Ábrán, Budapest 1999, s. 133-139.

Roszoncy I., Rol żeleznodorożnogo soobszczenija w okazanii Rossijej wojennoj pomoszczi Awstrii w maje 1849 g., „Sławianskij mir w trietjem tysiaczeletii” (Рошонци И., Роль железнодорожного сообщения в оказании Россией военной помощи Австрии в мае 1849 2., „САавянский мир в третьем тысячеметии”) 2018, Nº 3-4, s. 32-49.

Schnür-Pepłowski S., Polacy i Wegrzy. Opowieść dziejowa, Lwów 1898.

Schönhals von R., Biographie des k.k. Feldzeugmeisters Julius Freiherrn von Haynau, Wien 1875.

Skwarczyński J., Rozwój sieci kolejowej pod zaborem austriackim, „Inżynier Kolejowy” 1926, nr 8-9, s. 215-219.

Szczerbatow ks. A.P., Rządy księcia Paskiewicza w Królestwie Polskim (1832-1847), Warszawa 1900.

Szulcowie J. i E., Cmentarz ewangelicko-reformowany w Warszawie. Zmarli i ich rodziny, Warszawa 1989.

\section{Netografia}

Banach M., Most tańcuchowy w Budapeszcie, https://www.smartage.pl/most-lancuchowy-w-budapeszcie/ [dostęp: 12 I 2020].

Czarnotowie A. i L., Kolej Krakowsko-Górnośląska, „Gazeta Mysłowicka”, https://gazetamyslowicka.com/historia/2014/11/kolej-krakowsko-gornoslaska/ [dostęp: 7 XI 2014]. 
Lidiers, Aleksandr Nikotajewicz, graf (Аидерс, Александр Николаевич, граф), https://slovari. yandex.ru/ книги/Военная энцикмопедия/Аидерс, Александр Николаевич, граф/ [dostęp: 23 I 2020].

Stownik jezyka polskiego, red. W. Doroszewski (https://sjp.pwn.pl/doroszewski/natura; 5456548.html) [dostęp: 12 I 2020].

Stownik jezzyka polskiego PWN (https://sjp.pwn.pl/szukaj/natura) [dostęp: 12 I 2020].

\section{Jarosław Kita}

\section{NATURE VERSUS THE ARMY OF IVAN PASKEVICH DURING A EXPEDITION TO HUNGARY IN 1849}

Summary. In June 1849, the Russian intervention army under the command of Field Marshal Ivan Paskiewicz entered Hungary to provide support to the Austrian army. Several thousand Poles fought on the Hungarian side and some of them left diaries regarding the events of the Hungarian Spring of Nations. In turn, Poles also served in the Russian army, but we know very little of the documentaries created by them. Therefore, it is an interesting and little used source. In this text, based primarily on the memories of participants in the fighting in Hungary in 1849, historical reflection was taken on the problem to what extent nature influenced the activities carried out by the tsarist army. The authors of the memoirs did not write much about it, and if they already addressed this problem, they pointed to two main issues, namely the prevailing heat and the spreading cholera epidemic. In addition, some problems, although probably not the most important for memoirists, were crossing large rivers, such as the Cisa and long marches without food and water.

Keywords: Russian army, Revolutions of 1848, Hungary, Ivan Paskevich, nature 